\title{
Status and Woody Plant Species Diversity in Tara Gedam Forest, Northern Ethiopia
}

\section{Mohammed Gedefaw ${ }^{1^{\star}}$ and Teshome Soromessa ${ }^{2}$}

\author{
${ }^{1}$ Department of Natural Resource Management, University of Gondar, Post Box No: 196, Gondar, Ethiopia \\ ${ }^{2}$ Center for Environmental Science, Addis Ababa University, Post Box No: 1176, Addis Ababa, Ethiopia
}

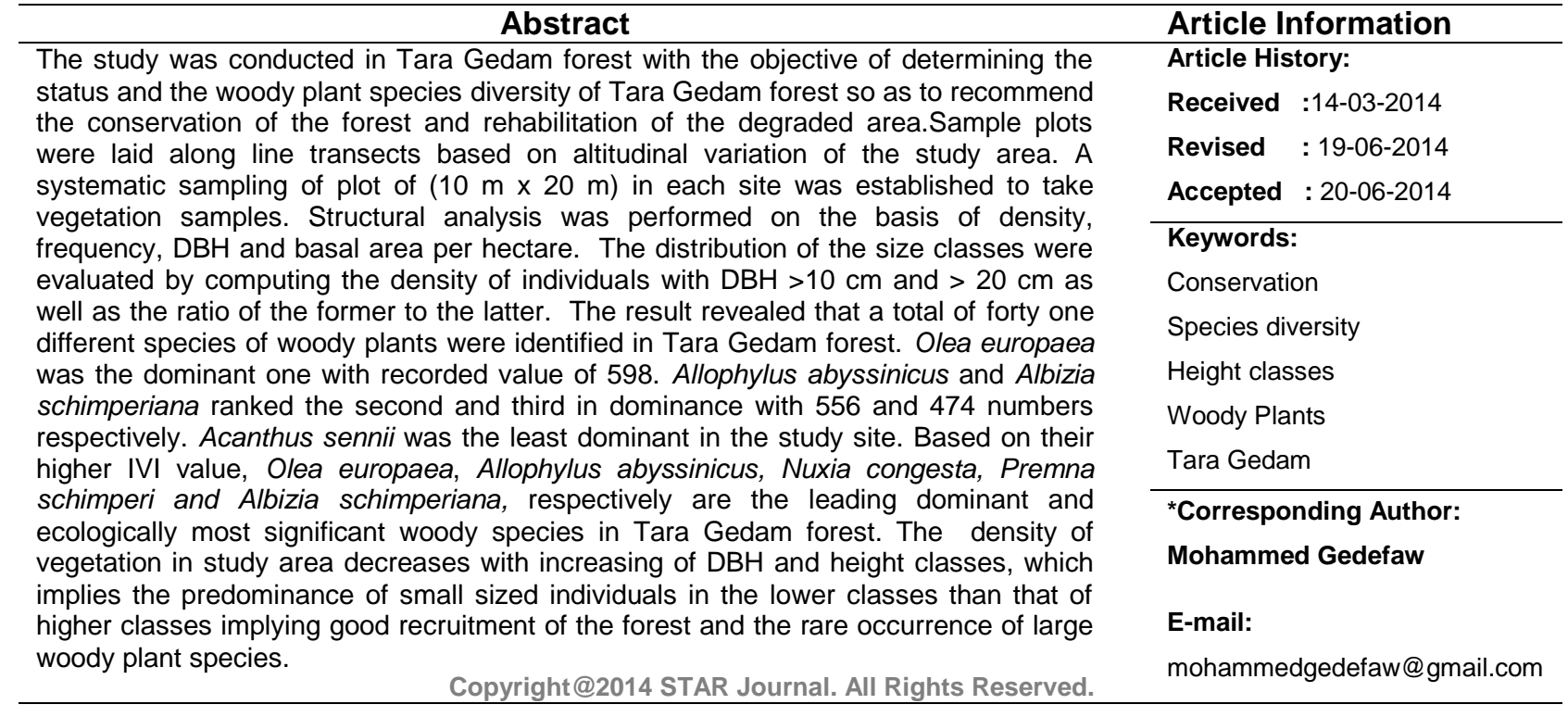

\section{INTRODUCTION}

Plants make up a vital part of the natural environment, and plant ecologists are well aware of this. In a healthy ecosystem, plants provide food and shelter for animals, secure the soil to prevent erosion, cast shade to create microclimates, conserve water to keep it in the ecosystem instead of allowing it to be lost, and participate in the breakdown and recycling of organic material to keep the ecosystem thriving. Plants are also of critical interest because they produce oxygen, and plants have been heavily implicated in the creation of the Earth's currently oxygen-rich atmosphere. The flora of Ethiopia is very heterogeneous and has a rich endemic element owing to the diversity in climate, vegetation and terrain. It is estimated to contain between 6,500-7000 species of higher plants, of which about $12 \%$ are endemic (Tewolde, 1991 as cited in Teshome Soromessa, et al., 2004). Endemism is particularly high in the high mountains and in the Ogaden area, southeastern Ethiopia. Despite these realities, the vegetation resources, particularly forests, are disappearing at a very alarming rate in Ethiopia before we even have a chance to study and document them (EFAP, 1994; Teshome Soromessa et al., 2004).
The plant populations on our planet must be sustained for all forms of life to exist on this planet being provided with the energy harvested from the sun by green plants through photosynthetic processes. The plant populations need to be maintained for the lives continue to exist on this planet as we know it through effective management measures. Various scholars also agreed on the urgency and importance of studying and documenting the vegetation resources of Ethiopia, among others, Teshome Soromessaet al. (2004); Ensermu Kelbessa and Teshome Soromessa (2008); Teshome Soromessa et al. (2011); Fekadu Gurmessa et al. (2011 and 2012); Adugna Feyissa et. al. (2013); Teshome Soromessa (2013); Teshome Soromessa and Ensermu Kelbessa (2013a and 2013b); Teshome Soromessa and Ensermu Kelbessa (2014); Mohammed Gedefaw et al. (2014) are the ones to mention. To implement the said effective management measures, one has to know relevant information pertinent to plant populations of a given ecosystem like plant diversity, composition and structures of a given habitat. Different methods have been developed to upgrade the knowledge of plant ecology by various scientific communities since time immemorial. Some methods and 


\section{Mohammed Gedefaw and Teshome Soromessa}

techniques are effective while others lack clarification and complicated.

Deforestation in the highlands of Ethiopia, specifically in the study area become an unstoppable process dating back many hundreds of years resulting patches of forest mainly around religious centers inaccessible and protected areas. They are the only areas covered by vegetation in Ethiopia (Alemayehu Wassie, 2007). The management and conservation of forests in all areas throughout the country has been becoming a big challenge since most of the activities did not involve the local community (Dessalegn Rahmato, 2001). The increasing of population growth increases the demand for forest products and this in turn puts a pressure on the natural forest to be degraded and facilitate the erosion process (Alemayehu Wassie and Demel Teketay, 2006).

Even if this study only covers very small area looking from the Ethiopian total forest coverage, it is important for sustainable forest management by achieving a win-win strategy. No study has been conducted in Tara Gedam forest that aimed at the status and floral diversity of vegetation. Therefore, the present study was initiated to

\section{Sci. Technol. Arts Res. J., April-June 2014, 3(2): 113-118}

investigate and document the diversity and status of species so as to provide information in order to manage the forest sustainably by planting trees and by conserving the natural forests as it is as well. The overall objective of this study is focused on the status and the floral diversity of Tara Gedam forest so as to recommend the conservation of the forest and rehabilitation of the surrounding area.

\section{MATERIALS AND METHODS \\ Description of the Study Area \\ Geographical Location}

The study was carried out in Tara Gedam forest located very close to Addis Zemen town, northeast of Lake Tana, northwestern Ethiopia (Figure 1). The study area is located in South Gondar Zone within the Amhara National Regional State. Addis Zemen town is located at $12^{\circ} 06^{\prime} 59^{\prime \prime} \mathrm{N}-12^{\circ} 07^{\prime} 25^{\prime \prime} \mathrm{N}$ and $37^{\circ} 46^{\prime} 14^{\prime \prime} \mathrm{E}-37^{\circ} 47^{\prime} 02^{\prime \prime} \mathrm{E}$, on the Addis Ababa Gondar main road, about $82 \mathrm{~km}$ north of Bahir Dar and $93 \mathrm{~km}$ south of Gondar town. The altitude of Tara Gedam ranges from 2217 to 2457 m.a.s.l. with the highest peak at Wombera Mountain. The forest covers 875 hectares.

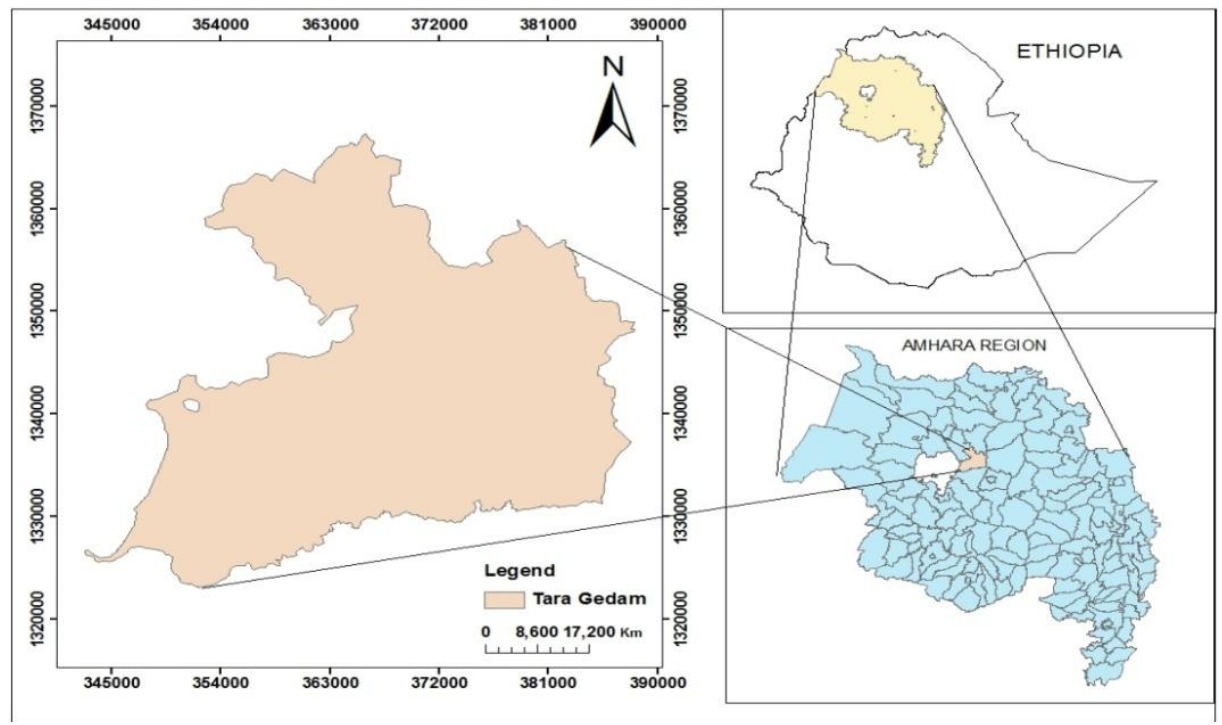

Figure 1: Location of Tara Gedam forest.

\section{Climate}

The study area is generally characterized by moderate climate, locally known as Woina Dega. The area has a mono modal rainfall distribution and the rainy season is from June to August. The dry season extends from December to March. Climatic data obtained from the National Meteorological Services Agency for the study area showed that the mean annual maximum and minimum temperatures are $27.9^{\circ} \mathrm{C}$ and $11.1^{\circ} \mathrm{C}$, respectively, and the mean annual rainfall is from $900 \mathrm{~mm}$ to $1,200 \mathrm{~mm}$.

\section{Geology and Soil}

Most of the areas are covered by volcanic rocks mainly basalt. The rocks are light dark, grey, whitish, reddish or brown. The fertility of the soils in the area deteriorated as a result of erosion and continuous cultivation.

\section{Vegetation Cover}

The vegetation of Tara Gedam consists of forests, bush lands, shrub lands and mixed/enrichment plantations. There is dense natural forest just around the monastery. Tara Gedam forests consist of different trees and shrubs interspersed with climbers and herbs.

\section{Delineation of the Study Site}

Delineation of theforest boundaries was the first step in floristic measurement. The boundary of the study forest area was delineated by taking geographic coordinates with GPS at each turning point. The GPS points that were taken from the study site to indicate each sample plots were recorded.

\section{Sampling Techniques in the Field}

Systematic sampling method was used to take samples. Sample plots were laid along line transects based on altitudinal variation of the study area. A systematic sampling of plot of $(10 \mathrm{~m} \times 20 \mathrm{~m})$ in each site was established. To collect information of woody speciescomposition, all live trees with a diameter $\geq 5 \mathrm{~cm}$ were recorded as indicated by (Pearson et al., 2005). 


\section{Mohammed Gedefaw and Teshome Soromessa}

For simplification of the study seedling, sapling and tree are defined as plants with heights up to $150 \mathrm{~cm}$, between $150-300 \mathrm{~cm}$ and above $300 \mathrm{~cm}$ respectively as used by (Demel Teketay, 1997). To determine seedling, sapling and tree densities and their distribution along the altitudinal gradient nine transects were established following North-South orientation and with $100 \mathrm{~m}$ distance interval between them. Sample plots were laid along line transects based on altitudinal variation of the study area. The diameter was measured at breast height $(\mathrm{DBH}, 1.3 \mathrm{~m}$ height from the ground) to estimate biomass and the size class distribution of trees in a sampling plot.DBH and height of plants were used to assess the structure of the study forest. Plant identification was done by using Flora of Ethiopia and Eritrea for those species difficult to identify in the field, fresh specimens were collected and then pressed properly and finally brought to the National Herbarium of Addis Ababa University.

\section{Methods of Data Analysis}

Different DBH classes were constructed, and the density distribution of tree and shrub species was computed in each class (McCune and Mefford, 1999; Magurran, 1988). Structural analysis was performed on the basis of density, frequency, DBH and basal area per hectare. The distribution of the size classes were evaluated by computing the density of individuals with $\mathrm{DBH}>10 \mathrm{~cm}$ and $>20 \mathrm{~cm}$ as well as the ratio of the former to the latter. According to Grubb et al. (1963), the ratio of 'density at $\mathrm{DBH}$ class $>10 \mathrm{~cm}$ to density at $\mathrm{DBH}$ class $>20 \mathrm{~cm}$ can be used as a measure of the distribution of the different size classes. The patterns of species population structure detected were interpreted as a sign for the alteration in population dynamics in the forests (Popma et al., 1988). The following structural parameters were calculated for some species following Mueller- Dombois and Ellenberg (1974) and Martin (1995) as follows:

Percent frequency of a species $=$ the number of plots in which that species occurs/total number of plots $X 100$

Relative frequency $=$ Frequency of species/total frequency of all species $X 100$

Density of a species $=$ the number of individuals of that species/area sampled

Relative density $=$ Density of species A/total density of all species $X 100$

Basal area $\left(\mathrm{m}^{2}\right)=(\mathrm{DBH} / 200)^{2} \mathrm{p}$ where $\mathrm{DBH}$ is the Diameter at Breast Height $(\mathrm{cm}), p=3.14$

Dominance $=$ Total of basal area $/$ area sampled

Relative dominance $=$ Dominance of species $\mathrm{A} /$ total dominance of all species X 100

Importance Value Index = Relative density + Relative frequency + Relative dominance.

\section{RESULTS AND DISCUSSION}

\section{Floristic Composition of the Forest}

A total of forty one different species of woody plants were identified in Tara Gedam forest, south Gondar Ethiopia. A total of 7,156 individuals of woody plants from the forty one different species were collected. Among the collected plant species, Olea europaea was the dominant one with recorded value of 598. Allophylus abyssinicus and Albizia schimperiana ranked the second and third in dominance with 556 and 474 numbers respectively. Acanthus sennii was the least dominant in the study site (Table 1).
Sci. Technol. Arts Res. J., April-June 2014, 3(2): 113-118

Based on the results (Table 1) Cupres suslusitanica had the highest percentage frequency $(12.50 \%)$. and the three tree species Dovyalis abyssinica, Clausena anisata and Urtica urens had the lowest percent frequency $(0.45 \%)$.

\section{Density}

The overall density of mature woody species of Tara Gedam forest $\mathrm{DBH}>5 \mathrm{~cm}$ was7, 156 stems ha $^{-1}$.

\section{Frequency}

Frequency is the number of quadrants in which a given species occurred in the study area. It gives an approximate indication for homogeneity and heterogeneity of vegetation. Lamprecht (1989) pointed out that high value in high frequency and lower value in the lower frequency classes indicate vegetation homogeneity. Conversely, high percentage of number of species in the lower frequency class and low percentage of number of species in the higher frequency classes indicates high degree of floristic heterogeneity (Simson Shibru and Girma Balcha, 2004). According to the result in Table 1 the highest frequency was recorded for Acacia senegal and the lowest for Dovyalis abyssinica.

\section{Diameter at Breast Height and Height Distribution of trees}

\section{Diameter at breast height (DBH)}

From the raw data collected from the field, the DBH of trees were classified into five classes: $0-10=, 11-20=, 21$ $30=, 31-40=$ and $>40=$ (Figure 2$)$. The majority of woody plants were distributed in the second class (11-20) followed by the third class (21-30) and the least woody plants on the other hand were recorded in the fifth and fourth classes respectively. This showed that the middle classes were occupied by dense and short plants.

\section{Height distribution of collected trees}

Like that of $\mathrm{DBH}$ distribution of plants, the height distribution of plants also was classified into five classes (0-10), (11-20), (21-30), (31-40) and (>40). The majority of tall plants were found in the second class like that of $\mathrm{DBH}$ classes followed by the first class. The shortest plants were recorded in the last two classes; fourth and five classes (Figure 3).

\section{Important Value Index (IVI)}

IVI is a combination of data from three parameters. These are: relative frequency, relative density and relative dominance (Kent and Cooker, 1992). Curtis and McIntosh (1951) pointed out that IVI gives a more realistic figure of dominance from structural point of view. It is useful to compare the ecological significance of species (Lamprecht, 1989) in which high IVI value indicates that the species sociological structure in the community is high. As a result ecologists consider IVI as the most reasonable aspect in the vegetation study (Curits and Mclntosh, 1951). Based on their higher IVI value, Olea europaea, Allophylus abyssinicus, Nuxia congesta, Premna schimperi and Albizia schimperiana, respectively are the leading dominant and ecologically most significant woody species in Tara Gedam forest. The leading dominant and ecologically most significant species might also be the most successful species in regeneration, pathogen resistance, grow in shade, and in completion with other species, least preferred by animals, attractions of pollinators and seed predators that facilitate seed dispersal within the existing environmental conditions of the study area (Table 2). 
Table 1: Species list collected from Tara Gedam forest with their average DBH, percentage of frequency, number of trees and the species that occurs more repeatedly in the whole plots.

\begin{tabular}{|c|c|c|c|c|c|}
\hline Species name & $\begin{array}{l}\text { No of } \\
\text { trees }\end{array}$ & $\begin{array}{l}\text { Average } \\
\mathrm{DBH}(\mathrm{cm})\end{array}$ & $\begin{array}{l}\text { No. of plots that } \\
\text { species found }\end{array}$ & $\begin{array}{c}\text { Average } \\
\text { height }\end{array}$ & $\begin{array}{c}\% \\
\text { Frequency } \\
\text { of species }\end{array}$ \\
\hline Acacia senegal L.Wild & 391 & 33.88 & 17 & 18.34 & 7.59 \\
\hline Acanthus sennii Chiov. & 2 & 10.46 & 3 & 13.79 & 1.34 \\
\hline Albizia schimperiana Oliv. & 474 & 38.52 & 16 & 19.00 & 7.14 \\
\hline Allophylus abyssinicus (Hochst) Radlkofer & 556 & 27.42 & 11 & 39.12 & 4.91 \\
\hline Anethum graveolens L. & 227 & 36.21 & 4 & 18.28 & 1.79 \\
\hline Bersama abyssinica Fresen. & 224 & 18.50 & 5 & 18.50 & 2.23 \\
\hline Brucea antidysenterica J.f.Mill. & 82 & 25.00 & 5 & 17.17 & 2.23 \\
\hline Buddleja polystachya Fresen. & 120 & 15.96 & 5 & 18.06 & 2.23 \\
\hline Calpurnia aurea (Ait) Benth. & 159 & 20.44 & 3 & 14.77 & 1.34 \\
\hline Carissa spinorum L. & 305 & 12.66 & 5 & 16.28 & 2.23 \\
\hline Celtis africana Brum.f. & 90 & 35.22 & 3 & 12.81 & 1.34 \\
\hline Clausena anisata (willd.) Hook. & 10 & 5.58 & 1 & 19.00 & 0.45 \\
\hline Combretum molle R.Br.ex G.Don & 233 & 20.55 & 3 & 16.34 & 1.34 \\
\hline Cordia africana Lam. & 75 & 31.00 & 2 & 13.77 & 0.89 \\
\hline Croton macrostachyus Del. & 379 & 37.59 & 10 & 20.61 & 4.46 \\
\hline Cupressus Iusitanica Mill. & 312 & 60.67 & 28 & 32.56 & 12.50 \\
\hline Dombeya torrida J.F.Gmel. & 127 & 30.89 & 4 & 16.67 & 1.79 \\
\hline Dodonaea angustifolia L.f. & 222 & 18.00 & 10 & 17.03 & 4.46 \\
\hline Dovyalis abyssinica (A.Rich.)Warb. & 19 & 36.85 & 1 & 14.42 & 0.45 \\
\hline Ekebergia capensis Sparrm. & 11 & 35.25 & 2 & 9.77 & 0.89 \\
\hline Eucalyptus globulus Labill. & 75 & 28.00 & 5 & 20.99 & 2.23 \\
\hline Euclea divinorum Hiern. & 80 & 14.35 & 6 & 13.23 & 2.68 \\
\hline Ficus sur Forssk. & 111 & 39.80 & 8 & 16.89 & 3.57 \\
\hline Grewia ferruginea Hochst.ex A.Rich. & 347 & 26.00 & 3 & 10.71 & 1.34 \\
\hline Hibiscus vitifolius $\mathrm{L}$. & 157 & 28.50 & 4 & 14.05 & 1.79 \\
\hline Hypericum quartinianum A.Rich. & 57 & 10.65 & 4 & 14.95 & 1.79 \\
\hline Jasminum grandiflorum $\mathrm{L}$. & 38 & 9.53 & 4 & 12.16 & 1.79 \\
\hline Maytenus arbutifolia (A.Rich.)Wilczek. & 181 & 22.34 & 5 & 14.50 & 2.23 \\
\hline Maytenus gracilipes (Welw.ex Oliv.) Exell. & 44 & 25.85 & 2 & 7.71 & 0.89 \\
\hline Myrsine africana $\mathrm{L}$. & 135 & 26.50 & 4 & 13.77 & 1.79 \\
\hline Nuxia congesta R.Br.ex Fresen. & 426 & 34.54 & 5 & 17.22 & 2.23 \\
\hline Olea europaea subsp.cuspidata. & 598 & 38.57 & 6 & 18.61 & 2.68 \\
\hline Osyris quadripartita Decn. & 100 & 24.75 & 6 & 15.60 & 2.68 \\
\hline Phytolacca dodecandra L'Herit & 3 & 16.00 & 2 & 12.00 & 0.89 \\
\hline Premna schimperi engl. & 356 & 38.80 & 5 & 17.75 & 2.23 \\
\hline Pterolobium stellatum (Forsk.) Brenan. & 133 & 10.25 & 6 & 13.94 & 2.68 \\
\hline Rosa abyssinica lindly. & 17 & 10.78 & 3 & 11.65 & 1.34 \\
\hline Schefflera abyssinica (Hochst.ex.A.Rich) Harms & 88 & 37.53 & 3 & 9.79 & 1.34 \\
\hline Schrebera alata (Hochst.)Welw. & 119 & 35.55 & 2 & 6.36 & 0.89 \\
\hline stereospermum kunthianum Cham. & 59 & 37.50 & 2 & 25.16 & 0.89 \\
\hline Urtica urens L. & 14 & 18.50 & 1 & 18.17 & 0.45 \\
\hline
\end{tabular}

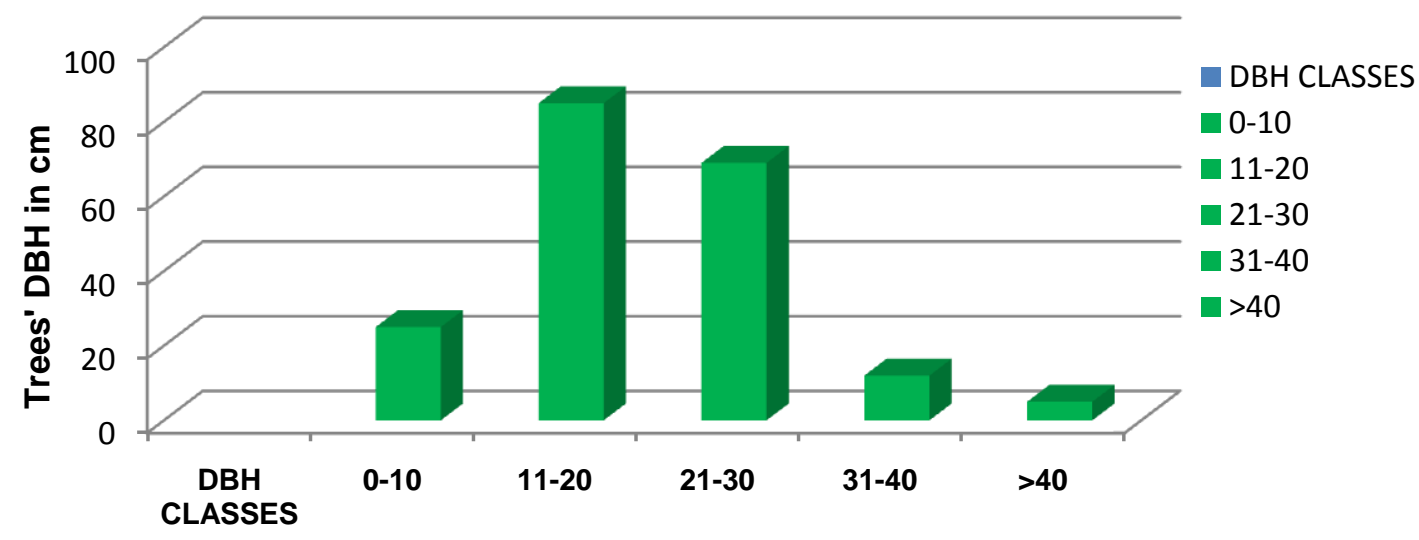

Figure 2: DBH distribution of plants in Tara Gedam forest 


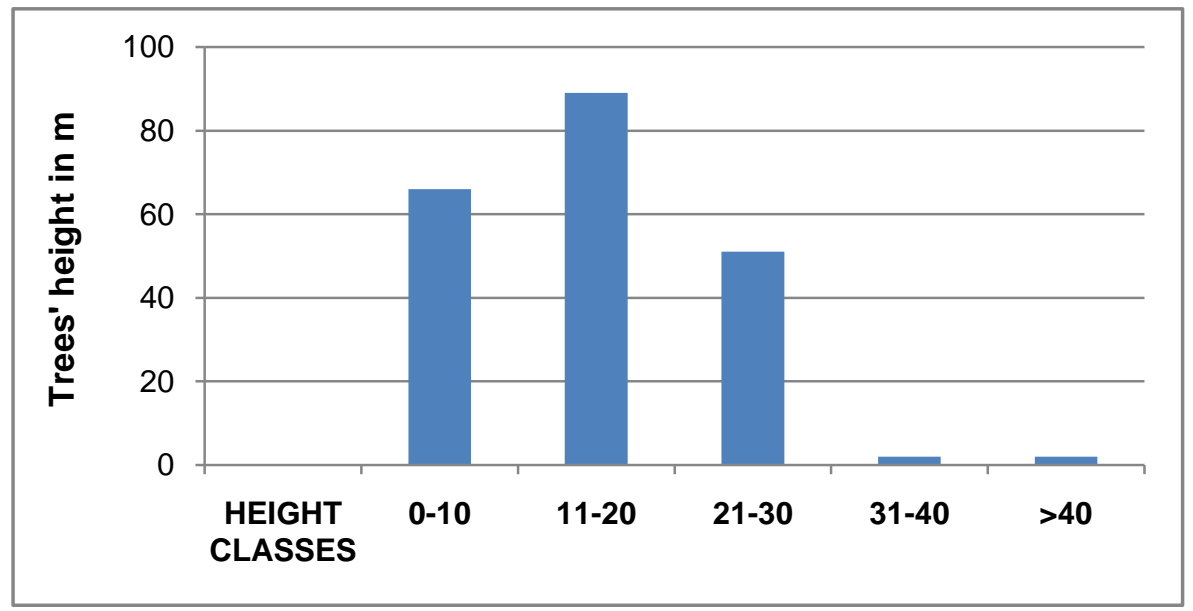

Figure 3: Height distribution of plants in the study forest

Table 2: Relative frequency, relative density and relative dominance and importance value index of the dominant woody species of Tara Gedam forest

\begin{tabular}{|c|c|c|c|c|}
\hline Name of species & $\begin{array}{c}\text { Relative } \\
\text { frequency }\end{array}$ & $\begin{array}{l}\text { Relative } \\
\text { density }\end{array}$ & $\begin{array}{c}\text { Relative } \\
\text { dominance }\end{array}$ & IVI \\
\hline Acacia senegal L. Wild & 7.59 & 5.463946 & 5.942738 & 18.99668 \\
\hline Acanthus sennii Chiov. & 1.34 & 0.027949 & 0.002897 & 1.370846 \\
\hline Albizia schimperiana Oliv. & 7.14 & 6.623812 & 9.312663 & 23.07648 \\
\hline Allophylus abyssinicus (Hochst) Radlkofer & 4.91 & 7.769704 & 5.535192 & 18.2149 \\
\hline Anethum graveolens $\mathrm{L}$. & 1.79 & 3.172163 & 3.940995 & 8.903158 \\
\hline Bersama abyssinica Fresen. & 2.23 & 3.13024 & 1.015113 & 6.375354 \\
\hline Brucea antidysenterica J.f.Mill. & 2.23 & 1.145892 & 0.678605 & 4.054496 \\
\hline Buddleja polystachya Fresen. & 2.23 & 1.676914 & 0.404734 & 4.311649 \\
\hline Calpurnia aurea (Ait) Benth. & 1.34 & 2.221912 & 0.879593 & 4.441505 \\
\hline Carissa spinorum L. & 2.23 & 4.262158 & 0.647277 & 7.139435 \\
\hline Celtis africana Brum.f. & 1.34 & 1.257686 & 1.478237 & 4.075923 \\
\hline Clausena anisata (willd.) Hook. & 0.45 & 0.139743 & 0.004123 & 0.593866 \\
\hline Combretum molle R.Br.ex G.Don & 1.34 & 3.256009 & 1.302874 & 5.898883 \\
\hline Cordia africana Lam. & 0.89 & 1.048072 & 0.95435 & 2.892421 \\
\hline Croton macrostachyus Del. & 4.46 & 5.296255 & 7.09099 & 16.84724 \\
\hline Cupressus Iusitanica Mill. & 12.5 & 4.359978 & 15.20637 & 32.06635 \\
\hline Dombeya torrida J.F.Gmel. & 1.79 & 1.774734 & 1.604584 & 5.169319 \\
\hline Dodonaea angustifolia L.f. & 4.46 & 3.102292 & 0.952404 & 8.514695 \\
\hline Dovyalis abyssinica (A.Rich.)Warb. & 0.45 & 0.265511 & 0.341627 & 1.057138 \\
\hline Ekebergia capensis Sparrm. & 0.89 & 0.153717 & 0.180981 & 1.224699 \\
\hline Eucalyptus globulus Labill. & 2.23 & 1.048072 & 0.778575 & 4.056646 \\
\hline Euclea divinorum Hiern. & 2.68 & 1.117943 & 0.218131 & 4.016074 \\
\hline Ficus sur Forssk. & 3.57 & 1.551146 & 2.328156 & 7.449302 \\
\hline Grewia ferruginea Hochst.ex A.Rich. & 1.34 & 4.849078 & 3.105984 & 9.295061 \\
\hline Hibiscus vitifolius $\mathrm{L}$. & 1.79 & 2.193963 & 1.688544 & 5.672507 \\
\hline Hypericum quartinianum A.Rich. & 1.79 & 0.796534 & 0.085605 & 2.672139 \\
\hline Jasminum grandiflorum L. & 1.79 & 0.531023 & 0.045697 & 2.36672 \\
\hline Maytenus arbutifolia (A.Rich.)Wilczek. & 2.23 & 2.529346 & 1.196101 & 5.955447 \\
\hline Maytenus gracilipes(Welw.ex Oliv.) Exell. & 0.89 & 0.614869 & 0.389311 & 1.89418 \\
\hline Myrsine africana $\mathrm{L}$. & 1.79 & 1.886529 & 1.255303 & 4.931832 \\
\hline Nuxia congesta R.Br.ex Fresen. & 2.23 & 5.953046 & 6.729414 & 14.91246 \\
\hline Olea europaea subsp.cuspidata. & 2.68 & 8.356624 & 11.77941 & 22.81603 \\
\hline Osyris quadripartita Decn. & 2.68 & 1.397429 & 0.811098 & 4.888527 \\
\hline Phytolacca dodecandra L'Herit & 0.89 & 0.041923 & 0.010169 & 0.942092 \\
\hline Premna schimperi engl. & 2.23 & 4.974846 & 7.096373 & 14.30122 \\
\hline Pterolobium stellatum (Forsk.) Brenan. & 2.68 & 1.85858 & 0.185022 & 4.723602 \\
\hline Rosa abyssinica lindly. & 1.34 & 0.237563 & 0.026158 & 1.603721 \\
\hline Schefflera abyssinica (Hochst.ex.A.Rich) Harms & 1.34 & 1.229737 & 1.641205 & 4.210942 \\
\hline Schrebera alata (Hochst.)Welw. & 0.89 & 1.66294 & 1.991357 & 4.544297 \\
\hline stereospermum kunthianum Cham. & 0.89 & 0.824483 & 1.098595 & 2.813078 \\
\hline Urtica urens L. & 0.45 & 0.19564 & 0.063445 & 0.709085 \\
\hline
\end{tabular}




\section{Mohammed Gedefaw and Teshome Soromessa CONCLUSION}

The study conducted in Tara Gedam forest showed that, the forest harbors many plant species. Based on the structural composition of $\mathrm{DBH}$ and height class distribution on Tara Gedam forest, similar trends have been shown in both $\mathrm{DBH}$ and height class classifications. The density of vegetation in the study area decreases with increasing of $\mathrm{DBH}$ and height classes, which implies the predominance of small sized individuals in the lower classes than that of higher classes implying good recruitment of the forest and the rare occurrence of large woody plant species.

The analysis of these two parameters in the study forest indicated that higher percentage numbers of plant species are found in the lower than in the higher frequency classes implying that the forest is floristically heterogeneous. The assessment of the status of vegetation in the study area showed that there was a significant proportion of woody species decline as a result of deforestation implying that they are under threat. Therefore, it is essential to develop and implement an effective conservation measures to save and use the biodiversity resources found in the forest in a sustainable manner.

\section{REFERENCES}

Adugna Feyissa, Teshome Soromessa and Mekuria Argaw (2013). Forest Carbon Stocks and Variations along Altitudinal Gradients in Egdu Forest: Implications of Managing Forests for Climate Change Mitigation. Science, Technology and Arts Research Journal 2(4): 4046.

Alemayehu Wassie (2007). Ethiopian Church forest: Opportunities and challenges for restoration, PhD dissertation, Wageningen University, Wageningen, The Netherlands.

Alemayehu Wassie and Demel Teketay (2006). Soil seed banks in Church forest of Northern Ethiopia: Implication for conservation of woody plants. Flora 201:32-43.

Curtis, J.T., and Macintosh, R.P. (1951).An upland forest continuum in the prairie forest border region of Wisconsin. Ecology 32:476-96.

Demel Teketay (1997). Seedling population and regeneration of woody species in dry afromontane forests of Ethiopia. Forest Ecology and Management 98:149-165.

Dessalegn Rahmato (2001). Environmental change and state policy in Ethiopia: Lessons from past experience. Forum for social studies, Addis Ababa.

Ensermu Kelbessa and Teshome Soromessa. (2008). Interfaces of Regeneration, Structure, Diversity and Uses of Some woody Species in Bonga Forest, a Unique Gene Reserve for Wild Coffee. SINET: Ethiopian Journal of Sciences 31(2): 121-134.

EFAP (1994). Ethiopian Forestry Action program, volume III. The challenge for Development. Ministry of Natural Resources, Addis Ababa.

Fekadu Gurmessa, Teshome Soromessa and Ensermu Kelbessa (2011). Florisitc Composition and Community analysis of Komto Afromontane Moist Forest of East Wellega, West Ethiopia. Science, Technology and Arts Research Journal 2(2): 58-69.

Fekadu Gurmessa, Teshome Soromessa and Ensermu Kelbessa (2012). Structure and Regeneration status of
Sci. Technol. Arts Res. J., April-June 2014, 3(2): 113-118

Komto Afromontane Moist forest, East Wellega Zone, West Ethiopia. Journal of Forestry Research 23 (2): 205216.

Kent, M., Coker, P. (1994). Vegetation Description and Analysis, Wiley, Chichester.

Lamprecht, H. (1989). Silviculture in the Tropics: Tropical Forest Ecosystems and Their Tree Species-Possibilities and Methods for their Long-term Utilization. Eschborn, Germany.

Magurran, A.E. (1988). Ecological diversity and measurement. Princeton University Press, Princeton, 354.Purdue University, Indiana. Basic Books, New York, pp573-603.

McCune, B. and Mefford, M.J. (1999). Multivariate Analysis of Ecological Data, Version 4.20.

Mohammed Gedefaw, Teshome Soromessa and Satishkumar Belliethathan (2014). Forest Carbon Stocks in Woody Plants of Tara Gedam Forest: Implication for Climate Change Mitigation. Science, Technology and Arts Research Journal 3(1): 101-107.

Muller-Dombois, D. and Ellenberg, H. (1974). Aims and Methods of Vegetation Ecology. John Wiley and Sons. Inc. New York. Pp 547.

Pearson, T., Walker, S. and Brown, S. (2005). Source book for land-use, land-use change and forestry projects. Winrock International and the Bio-carbon fund of the World Bank. Arlington, USA, pp. 19-35.

Popma, J., Bongers, F. and Meave del Castillo, J. (1988). Patterns in the vertical structure of tropical lowland rain forest of Los Tuxtals, Mexico. Vegetation 74: 81-91.

Simon Shibru and Girma Balcha (2004). Composition, structure and regeneration status of woody species in Dindin Natural Forest, Southeast Ethiopia; An implication for conservation. Ethiopian Journal of Biological Science 3:15-35.

Teshome Soromessa., Demel Teketay and Sebsebe Demissew. (2004). Ecological study of the vegetation in Gamo Gofa zone, Southern Ethiopia. Tropical Ecology 45(2): 209-221.

Teshome Soromessa, Ensermu Kelbessa, Afework Bekele, Getinet Masresha, Desalegn Ejigu, Melese Yihune and Fissehaltanna (2011). Current Status and Significance of Faunal and Floral Diversity of the Simien Mountains, Northern Ethiopia. A poster presented on December 3031, 2011 during the conference on Thematic Research Organized by Addis Ababa University, Addis Ababa, Ethiopia.

Teshome Soromessa (2013). Ecological Phytogeography: A Case Study of Commiphora Species. Science, Technology and Arts Research Journal 2(3): 93-104.

Teshome Soromessa and Ensermu Kelbessa (2013a). Diversity, Ecology and Regeneration Studies of Bonga, Borana and Chilimo Forests of Ethiopia. Lambert Academic Publishing, Saarbrücken, Germany, Pp 140, ISBN 978-3-659-41509-8.

Teshome Soromessa and Ensermu Kelbessa (2013b). Diversity and Endemicity of Chilimo Forest, Central Ethiopia. Bioscience Discovery 4(1): 1-4.

Teshome Soromessa and Ensermu Kelbessa (2014). Interplay of regeneration, structure and uses of some woody species in Chilimo Forest, Central Ethiopia. Science, Technology and Arts Research Journal 3(1): 90100. 